\title{
Community pharmacy-based research in Spain (1995-2005): A bibliometric study
}

José Carlos ANDRÉS IGLESIAS, N. Floro ANDRÉS RODRÍGUEZ, José Antonio FORNOS PÉREZ.

\begin{abstract}
${ }^{*}$
Only one study evaluated the scientific activity in community pharmacies in Spain, and it was restricted to articles published in just two journals. Objective: To assess the scientific activity in community pharmacies in Spain through a bibliometric analysis of the original papers published during the years 1995-2005.

Methods: IPA, MEDLINE, CSIC database and the journals Seguimiento Farmacoterapéutico y Pharmaceutical Care España were used as data sources. Production indicators, consumption indicators and the impact factor (IF) as a repercussion index were analyzed.

Results: 122 articles were included in the review. The articles were published in 12 journals, $78.7 \%$ of them in Pharmaceutical Care España and Seguimiento Farmacoterapéutico. The mean number of authors per article was $4.2(\mathrm{SD}=2.1)$. The transitivity index was $71.3 \%$. The total number of references cited in the articles was 2110 . The mean number of references per article was 17.3 SD=9.3. The value of the insularity index was $57.6 \%$. Self citation was $6.8 \%$ and the Price index was $66.5 \%$. No impact factor was available for 6 journals. Conclusions: Publication of articles on community pharmacy-based research in Spain has undergone an important increase in the last 5 years. The existence of authors who publish very few studies, the high insularity index and the lack of randomized, controlled trials may be considered as negative indicators in community pharmacy-based research in Spain.
\end{abstract}

Keywords: Pharmacies. Bibliometrics. Authorship. Spain.

\begin{abstract}
RESUMEN
Sólo existe un estudio bibliométrico conocido sobre investigación en farmacia comunitaria en España, y estaba centrado en los trabajos publicados únicamente en dos revistas. Objetivo: Evaluar la actividad científica en investigación en farmacia comunitaria en España realizando un análisis bibliométrico de los artículos originales publicados entre los años 1995-2005.

Métodos: Se utilizaron como fuentes de datos IPA, MEDLINE, la base de datos del CSIC y las revistas Seguimiento Farmacoterapéutico y Pharmaceutical Care España. Se analizaron indicadores de producción, indicadores de consumo e indicadores de repercusión de los artículos publicados. Resultados: Se incluyeron 122 artículos en la revisión. Los artículos fueron publicados en 12 revistas, el 78,7\% en Pharmaceutical Care España y Seguimiento Farmacoterapéutico. El número medio de autores por artículo fue 4,2 (DE=2,1). El índice de transitoriedad fue de 71,3\%. El número total de referencias encontradas en los artículos fue de 2110 (17,3 $\mathrm{DE}=9,3$ por artículo). El índice de aislamiento fue de $57,6 \%$, el porcentaje de autocitación de 6,8\% y el índice de Price de 66,5\%. No se pudo estudiar el FI de 6 revistas. Conclusiones: La publicación de artículos de investigación en la farmacia comunitaria en España ha experimentado un crecimiento importante en los últimos 5 años. La existencia de autores que publican muy poco, el elevado índice de aislamiento y la falta de estudios experimentales controlados y aleatorizados pueden considerarse como indicadores negativos de la investigación en farmacia comunitaria en España.
\end{abstract}

Palabras clave: Farmacias. Bibliometría. Autoría. España.

\section{(English)}

\section{INTRODUCTION}

In the last decade, Spanish community pharmacies have incorporated into their existing services a series of extra activities included within the concept of Pharmaceutical Care, with the aim of achieving the maximum benefit from patients' therapy. These activities are endorsed by the new Spanish law of Guarantees and Rational Use of Medicines and Medical Devices. ${ }^{1}$
José Carlos ANDRÉS IGLESIAS*. BScPharm. Community pharmacist at Vigo, Pontevedra (Spain). N. Floro ANDRÉS RODRÍGUEZ. PhD. BScPharm. Community pharmacist at Vigo, Pontevedra (Spain). José Antonio FORNOS PÉREZ. PhD. BScPharm. Community pharmacist at Cangas, Pontevedra (Spain). 
Although implementation of these activities in daily practice has generally been lower than initially hoped, the challenges inherent in pharmaceutical care and pharmacists' services in general, have been taken on by a large number of pharmacists in Spain. As evidence of this is the appearance of specialized journals such as Seguimiento Farmacoterapéutico and Pharmaceutical Care España. There has also been a noteworthy increase in the number of communications presented at conferences focusing in community pharmacies and pharmaceutical care. At the last Spanish National Congress on Pharmaceutical Care, held in Valencia $^{2}$ in 2005 , the number of communications was three times the number at the First National Congress on Pharmaceutical Care, held in San Sebastián in 1999. ${ }^{3}$

To achieve greater dissemination and implementation of pharmaceutical care and to confirm the value of the system, research to demonstrate the effectiveness of interventions by community pharmacists must be undertaken. This can be extended to the other services that community pharmacies offer, such as pharmacovigilance and health promotion.

Review of the scientific literature helps researchers to obtain information about the current state of research in particular areas, and how the system is working and designs being used. This allows researchers to identify and undertake new lines of research. Bibliometric analysis is a useful tool for obtaining information about scientific activity in a certain field or area.

Reviews of the scientific literature concerning community pharmacies in different countries ${ }^{4,5}$ and of pharmaceutical care in particular have been made $^{6}$, but there is no up-to-date review of research carried out in Spanish community pharmacies. The last known bibliometric study of community pharmacy research in Spain $^{7}$ was carried out a decade ago and was centred on articles published in just two journals.

The aim of this study was to assess the scientific activity in Spanish community pharmacy through a bibliometric analysis of the original papers published during the years 1995-2005.

\section{METHODS}

A search for community pharmacy-based research published in biomedical journals in Spain in the period between January 1995 and December 2005 was carried out by using the following databases: International Pharmaceutical Abstracts $(\text { IPA })^{8}$, Medline $^{9}$, and the Spanish National Research Council $(\mathrm{CSIC}){ }^{10} \mathrm{~A}$ direct search was made in primary sources, specifically in the journals Seguimiento Farmacoterapéutico and Pharmaceutical Care España.

For the PubMed/MEDLINE search, the term community was used in combination with pharmac* and Spain, and the search was limited to the period above mentioned. In another search the term community was combined with pharmac* and the search was limited to articles originally published in Spanish. The term "pharmacy office" was used in another search.

For the search involving the CSIC database, the keywords farmacia* ${ }^{*}$ comunitaria*, oficina* de $^{*}$ farmacia and atención farmacéutica y farmacia were used. These searches were conducted in the IME (biomedicine) and ICYT (science and technology) summaries.

In the IPA search the terms "community pharmac", "pharmaceutical care and community", "community pharm* and Spain" were used and the search was limited to the period between 1995-2005.

The title and the abstract of the documents retrieved were examined to identify original articles, i.e., those presenting the results of original research, which has not been published previously and the structure of which usually follows the IMRD format (Introduction, Methods, Results and Discussion). Short communications presenting original research were also revised. When it was not clear from the abstract whether the study was original or not, the text of the article was revised. Articles that did not present the results of original work -such as review articles, articles expressing opinions or describing protocols- were excluded from review. Original articles by authors who were not community pharmacists (none of the authors), or studies that did not involve at least the participation of community pharmacists in the design and development of the research, were also excluded. The selection was made independently by two reviewers.

The articles retrieved were entered into a Microsoft Access database. The variables registered for each article were: main author, number of authors, year of publication, journal, objective, design and area of study, existence of grants or official funding and the number, year and origin of the bibliographic references.

Production indicators: The change in the number of publications in the period studied, the number of authors per publication, transitivity index (percentage of occasional authors with respect to total number of authors) and the scientific productivity per autonomous community were used as production indicators. To measure authors' productivity, Lotka's law ${ }^{11}$ was applied. The Lotka productivity index (decimal logarithm of the number of articles published) enabled grouping of authors according to their level of productivity: low productivity (1 publication and productivity index equal to 0 ), intermediate productivity (2-9 published articles and productivity index greater than 0 and less than 1) and high productivity (10 or more published articles and productivity index greater than or equal to 1$).^{12}$

Consumption indicators: The number of references per article, the percentage of self citations, the number of references in languages other than Spanish, the insularity index (percentage of references from the same country as the journal in which they were cited), Price index (percentage of references published within the past 5 years), the 
different types of sources of the references and dispersal of references from primary sources, according to Bradford's Law, were all recorded to obtain information about which journals are most commonly used by community pharmacists in their research. To identify the body of journals that comprise Bradford's nucleus, the method proposed by Ferreiro ${ }^{11}$ was used.

Repercussion indicators: The impact factor of the journals in which the articles were published was studied as an indicator of repercussion.

The data obtained in the study was analysed by the G-Stat 2.0 statistical programme. Qualitative data were expressed as percentages and quantitative data as means (standard deviation).

\section{RESULTS}

491 articles were retrieved from the databases, and after excluding duplicated articles, only 26 complied with the inclusion criteria. A further 22 valid articles were found in Seguimiento Farmacoterapéutico, and 74 in Pharmaceutical Care España; a total of 122 articles were therefore included in the review. ${ }^{13-}$ 134

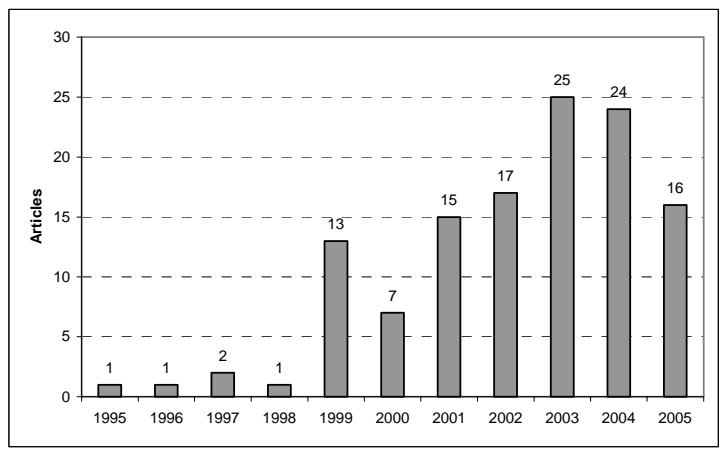

Figure 1. Distribution of articles by year of publication

Of the articles retrieved, $11.5 \%$ were short communications, and $15.6 \%$ of the studies acknowledged receipt of some kind of grant or funding. The increase in the number of articles published in the period under consideration is shown in Figure 1. The articles finally included for consideration were published in 12 journals (Table 1 ), and $78.7 \%$ of the articles were published in Pharmaceutical Care España or Seguimiento Farmacoterapéutico. In 8 of the articles $(6.6 \%)$ the original language was English, whereas the remaining articles were written in Spanish. These 8 articles were included in journals published in The Netherlands (Pharmacy World \& Science), United States (Headache, The Annals of Pharmacotherapy and American Journal of Health-System Pharmacy) and New Zealand (Clinical Pharmacokinetics).

Of all of the articles selected, $24.6 \%$ were written by research groups, led by the Pharmaceutical Care Research group at the University of Granada (GIAFUGR), with 9 studies of their own and 3 studies in collaboration with the Applied Pharmacology and Pharmacotherapy research group at the University of Seville (who also produced 2 articles of their own) and followed by the Berbés Pharmaceutical Care group (Pontevedra), with 4 articles.

\begin{tabular}{|c|c|c|}
\hline Journal & $\begin{array}{l}\text { Articles } \\
\text { published }\end{array}$ & IF (year) \\
\hline $\begin{array}{ll}\text { Pharmaceutical } & \text { Care } \\
\text { España } & \\
\end{array}$ & 74 & No \\
\hline $\begin{array}{l}\text { Seguimiento } \\
\text { Farmacoterapéutico }\end{array}$ & 22 & No \\
\hline Atención Primaria & 6 & No \\
\hline Atención Farmacéutica & 5 & No \\
\hline Ars Pharmaceutica & 4 & No \\
\hline Annals of Pharmacotherapy & 2 & $1.837(2005)$ \\
\hline Pharmacy World \& Science & 2 & $1.009(2005)$ \\
\hline $\begin{array}{l}\text { Revista Española de Salud } \\
\text { Pública }\end{array}$ & 2 & $0.388(2003)$ \\
\hline Headache & 2 & $2.455(2005)$ \\
\hline Clinical Pharmacokinetics & 1 & $5.195(2005)$ \\
\hline $\begin{array}{l}\text { American Journal of Health- } \\
\text { System Pharmacy }\end{array}$ & 1 & $1.437(2005)$ \\
\hline $\begin{array}{lrl}\text { Revista Española } & \text { de } \\
\text { Nutrición Comunitaria } & \\
\end{array}$ & 1 & No \\
\hline
\end{tabular}

The total number of authors of the revised articles was 512, which corresponded to 313 different individuals. Only 8 articles were written by a single author and the mean number of authors per article was $4.2(S D=2.1)$. The distribution of the 512 signatories according to professional status showed a clear predominance of articles by community pharmacists $(69.1 \%)$. The transitivity index was $71.3 \%$ (223 authors from the total of 313 authors only published one article). The number of authors listed according to the number of papers published and the production index for the authors are shown in Table 2. This distribution corresponds to an exponential curve described by the equation $A n=$ $193.7 \mathrm{n}-2.2$ and log transformation provides a straight line with a correlation coefficient of 0.93 .

\begin{tabular}{|c|c|c|c|c|c|c|c|c|c|c|}
\hline \multicolumn{2}{|c|}{ Table 2. Number of authors according to the number of papers published } \\
\hline $\begin{array}{c}\text { Number of } \\
\text { articles }\end{array}$ & 1 & 2 & 3 & 4 & 5 & 6 & 7 & 8 & 9 & 14 \\
\hline $\begin{array}{c}\text { Authors } \\
(\%)\end{array}$ & $\begin{array}{c}223 \\
(71.3 \%)\end{array}$ & $\begin{array}{c}43 \\
(13.7 \%)\end{array}$ & $\begin{array}{c}26 \\
(8.3 \%)\end{array}$ & $\begin{array}{c}7 \\
(2.2 \%)\end{array}$ & $\begin{array}{c}6 \\
(1.9 \%)\end{array}$ & $\begin{array}{c}2 \\
(0.6 \%)\end{array}$ & $\begin{array}{c}1 \\
(0.3 \%)\end{array}$ & $\begin{array}{c}2 \\
(0.6 \%)\end{array}$ & $\begin{array}{c}2 \\
(0.6 \%)\end{array}$ & $\begin{array}{c}1 \\
(0.3 \%)\end{array}$ \\
\hline $\begin{array}{c}\text { Productivity } \\
\text { index }\end{array}$ & 0 & 0.30 & 0.48 & 0.60 & 0.70 & 0.78 & 0.85 & 0.90 & 0.95 & 1.15 \\
\hline
\end{tabular}

The total number of references cited in the articles was 2110. The mean number of references per article was $17.3 \quad(\mathrm{SD}=9.3)$. The number of references in languages other than Spanish was $887(42.0 \%$ of the total number of references), of which $99.7 \%$ were in English, and with a mean number of $7.3(S D=8.2)$ references per article in a language other than Spanish. The value of the index of isolation was $57.6 \%$. The percentage of self citation was 6.8 and the value of Price index was 
$66.5 \% .1608(76.2 \%)$ references were to journal articles, $254(12.0 \%)$ to book and dissertations, $79(3.7 \%)$ references to legislative documents, 60 $(2.8 \%)$ references to clinical guides and monographs, $56(2.7 \%)$ to the Internet and press, and $53(2.6 \%)$ to courses and communications in congresses. The 1608 references from primary sources appeared in a total of 349 journals. The journals comprising Bradford's nucleus, calculated according to the method of Ferreiro ${ }^{11}$ are shown in Table 3.

\begin{tabular}{|c|c|}
\hline Journals & References \\
\hline Pharmaceutical Care & 221 \\
\hline Atención Primaria & 92 \\
\hline Medicina Clínica & 58 \\
\hline $\begin{array}{l}\text { American Journal of Health-System } \\
\text { Pharmacy }\end{array}$ & 55 \\
\hline British Medical Journal & 49 \\
\hline El farmacéutico & 40 \\
\hline Ars Pharmaceutica & 36 \\
\hline $\begin{array}{l}\text { Journal of the American Pharmacists } \\
\text { Association }\end{array}$ & 35 \\
\hline ITSNS / Annals of Pharmacotherapy & 34 \\
\hline Atención Farmacéutica/ JAMA ${ }^{\dagger}$ & 32 \\
\hline Farmacia Profesional & 26 \\
\hline Archives of Internal Medicine/ Lancet & 25 \\
\hline TOTAL & 794 \\
\hline
\end{tabular}

The impact factors (IF) of the journals in which the articles were published are shown in table 1 .

As regards the study design, $86.9 \%$ of the studies were descriptive, $11.5 \%$ quasiexperimental and $1.6 \%$ controlled, randomized experimental studies.

\section{DISCUSSION}

A fundamental part of research involves communication of the results in any way. In the present study, bibliometric indicators were used to describe the scientific activity in community pharmacies in Spain between 1995 and 2005. The bibliometric indicators used showed certain limitations, but allowed some understanding of the research activity for the period considered ${ }^{135}$. Furthermore, as three databases and two primary sources were examined, not all original articles corresponding to community pharmacy-based research in Spain during the period considered may have been retrieved.

The 122 articles on community pharmacy-based research (11.1 articles per year) represented a low rate of production compared with the rate of production of original articles in other fields in which there exists more experience in scientific research, such as hospital pharmacy. Hospital pharmacists published 260 articles in Farmacia Hospitalaria between 1995 and 2005. ${ }^{136}$ Production of scientific articles in community pharmacies in Spain is, however, similar to that in other countries, such as for example, Canada; in Canada, 38 original articles $^{5}$ were published between 1995 and 2001, and 40 original articles were published in Spain in the same period. In a study of worldwide research in Pharmaceutical Care in the past 5 years ${ }^{6}$, Spain occupied a high position in terms of production, below the USA, at the same level as the UK and above countries such as France, Italy and Germany.

Our study showed that scientific output in community pharmacy research has notably increased in the study period. Only 25 articles were published in the first 6 years, between 1995 and 2000, whereas some 97 articles were published between 2001 and 2005. However, in 2005 there was a slight decrease in the numbers of articles published.

The increase in the number of articles published appears to be related to the appearance in Spain of specialized journals such as Pharmaceutical Care España and Seguimiento Farmacoterapéutico. The number of original articles published rose from 1 in 1998 to 13 in 1999, coinciding with the release of the first volume of Pharmaceutical Care España, and from 17 in 2002 to 25 in 2003, the year in which the journal Seguimiento Farmacoterapéutico first appeared. The two journals published $78.7 \%$ of the articles considered, which demonstrates their importance in diffusion of community pharmacybased research in Spain, and indicates the need for such specialized journals in which pharmacists can publish their work. The fact that in 2005 there was a decrease in the number of original articles may be partly attributed to the fact that one of the threemonthly issues of the journal Pharmaceutical Care España was not published.

The research groups make an important contribution to community pharmacy-based research. Most of the studies carried out by these groups were published in the latter years of the period considered, which demonstrates consolidation and an increase in the number of groups. The work carried out by these groups is not limited to research or collaboration with other researchers and their activities also include training of other pharmacists in research methods and in pharmaceutical practice, and the promotion and diffusion of pharmaceutical care.

The transitivity index observed was high, with $71.3 \%$ of the authors included only having published one article. Some 223 of the authors showed low productivity, 89 authors intermediate activity and only 1 author was rated as highly productive. The fact that most authors have published only one article reflects a lack of continuity in research, partly resulting from the exceptional nature of the research carried out by some authors and also the lack of consolidation in community pharmacy-based research, which is largely due to the lack of time available to pharmacists for carrying out research studies.

Some $40.7 \%$ of the references were in a language other than Spanish, and most were in English. The insularity index (57.6\%) was higher than that observed in the analysis of consumption of information in journals in other fields and disciplines such as Farmacia Hospitalaria $(25 \%)^{137}$, Cirugía 
Española (13.2\%) ${ }^{138}$ and Medicina Clínica (14\%). ${ }^{139}$ This indicates a lack of quality in the bibliographic review, which is often restricted to the most accessible sources of information.

Some $75.7 \%$ of the references originated from primary sources of information, which indicates the importance of journals as the main mechanisms of research diffusion. ${ }^{140}$

The high Price index (66.9\%) may be attributable to the early stage of development of community pharmacy-based research and therefore the relative recentness of the studies that can be cited.

Analysis of primary sources scattering used revealed a nucleus of 15 journals, which are the most commonly used for carrying out research studies. Pharmaceutical Care España was the most important of these journals. Bradford's nucleus did not contain the journal Seguimiento Farmacoterapéutico, probably because of its short life since the first volume was published in 2003. The nucleus of publications represented $4.3 \%$ of the total number of primary publications, but contained $49.4 \%$ of the total number of references cited. Of the 15 journals, 7 (46.7\%) are published in English.

The Institute for Scientific Information (ISI: Philadelphia, USA) calculates the yearly IF for all journals included in the Science Citation Index, the Social Science Citation Index and the Arts \& Humanities Citation Index databases and publishes them in the Journal Citation Reports (JCR). ${ }^{141}$ Many Spanish journals are not included in these databases ${ }^{142}$, and thus a study entitled "Potential impact factors of Spanish medical journals", ${ }^{143}$ was carried out with the purpose of determining the national and international IF of Spanish biomedical journals. The international IF is the impact factor that would be assigned to the databases considered by the ISI.
A single IF was assigned to the journals for the period considered because the interannual variation in IF is very low. ${ }^{144}$ The absence of IF for several of the journals, including the two in which most of the articles were published places doubts on the usefulness of IF to indicate the state of community pharmacy-based research in Spain.

Most studies carried out in community pharmacies are descriptive, and there is a lack of analytical studies, particularly those involving controlled, randomized experiments. This appears to be a common situation in research in Pharmaceutical Care. ${ }^{6,145}$

Controlled, randomized experimental studies provide the best scientific evidence ${ }^{146}$ and are necessary for demonstrating that interventions by community pharmacists have positive repercussions on the health of patients. Furthermore, the researchers should meet the standards of quality for these types of studies. ${ }^{147}$

\section{CONCLUSIONS}

Publication of articles on community pharmacybased research in Spain has undergone an important increase in the last 5 years, partly due to the appearance of specialized journals.

The contribution of research groups is fundamental for the future of community pharmacy-based research.

The existence of authors who publish very few studies and the high insularity index observed in the articles may be considered as negative indicators in community pharmacy-based research in Spain.

The research carried out in community pharmacies should include more scientific evidence, obtained by correctly designed controlled, randomized experiments.

\section{References}

1. Ley de garantías y uso racional de los medicamentos y productos sanitarios. Ley 29/2006 de 26 de julio. Boletín Oficial del Estado, no 178, (27/7/2006).

2. IV Congreso Nacional de Atención Farmacéutica. Pharm Care Esp 2005; 7(Extr):1-192.

3. Libro de ponencias y comunicaciones. I Congreso Nacional de Atención Farmacéutica. San Sebastián, 28 a 30 de octubre de 1999. San Sebastián: Colegio de Farmacéuticos de Guipúzcoa; 2000.

4. Roughead L, Semple S, Vitry A. The value of pharmacist professional services in the community setting: a systematic review of the literature 1990-2002. Available at: http://beta.guild.org.au/research/funded_projects.asp. (Accessed 1006-2006).

5. Sokar-Todd HB, Einarson TR. Community pharmacy practice research: a systematic review of the past 32 years. Can Pharm J 2003;136(8):26-38.

6. Rangel Mayoral JF, Luis Fernández J, Liso Rubio FJ. Estado actual de la investigación en atención farmacéutica. Farm Hosp 2005;29(5):335-42.

7. Del Arco Ortiz de Zarate J. La investigación en farmacia comunitaria. Trabajos publicados en Atención Primaria y Farmacia Clínica (1992-1995). Farm Clin 1996;13(2):118-23.

8. International Pharmaceutical Abstracts. [Base de datos en Internet]. Thomson Scientific; 1970- Available at: http://web.ebscohost.com/ehost. (Accessed 24-05-2006).

9. PubMed [Base de datos en Internet]. Bethesda: Nacional Library of Medicine; 1966- Avaiable at: http://www.ncbi.nlm.nih.gov/entrez/query.fcgi?DB=pubmed. (Accessed 20-05-2006).

10. Bases de datos bibliográficas del CSIC [Base de datos en Internet]. Madrid: CSIC; Available at: http://bddoc.csic.es:8080/index.jsp. (Accessed 18-05-2006).

11. Ferreiro Aláez L. Bibliometría (Análisis bivariante). Madrid: Eypasa: 1993. 
12. López Piñero JM, Terrada ML. Los indicadores bibliométricos y la evaluación de la actividad médico-científica (III). Los indicadores de producción, circulación, dispersión, consumo de la información y repercusión. Med Clin (Barc) 1992;98:142-8.

13. Andrés Rodríguez NF, García Riestra R, Ocampo Hermida MT, Fernández-Llimós Somoza F. Perfil de los integrantes de los grupos de trabajo del Colegio de Farmacéuticos de Pontevedra. Pharm Care Esp 2000;2(1):20-7.

14. Loza García MI, Cordero Puentes L, Fernández-Llimós Somoza F, García Corral P, Cadavid Torres MI, Sanz i Carreras $\mathrm{F}$ et al. Fuentes de información sobre medicamentos utilizadas por los farmacéuticos comunitarios de Galicia. Pharm Care Esp 2000;2(2):108-22.

15. Sanz F, Silveira C, Díaz C, Alonso A, Loza MI, Cordero L et al. Information technology in community pharmacies for supporting responsible self-medication. Am J Health Syst Pharm 2000;57(17):1601-3.

16. Del Arco Ortiz de Zárate J, Núñez Babarro J, Aburto Goiri AM. La evolución de los grupos de trabajo del Colegio Oficial de Farmacéuticos de Bizkaia de 1990 a 2000. Pharm Care Esp 2003;5(2):88-93.

17. Zardain Tamargo E, López Gonzalez ML. Categorización de los factores psicosociales del seguimiento farmacoterapéutico en el modelo ASE, en farmacéuticos de oficina de farmacia. Pharm Care Esp 2003;5(5):216-25.

18. Acosta Gómez J, Alzaga A, Álvarez Mozos L, Gudiel M, Fernández-Llimós F. Estructura y servicios de atención farmacéutica ofrecidos en farmacias de Alcorcón (Madrid) y Bilbao. Seguimiento Farmacoterapéutico 2003;1(3):120-3.

19. Cordero L, Cadavid MI, Fernández-Llimós F, Díaz C, Sanz F, Loza MI. Continuing education and community pharmacists in Galicia: a study of opinions. Pharm World Sci 2004;26(3):173-7.

20. Aguas Y, De Miguel E, Fernández-Llimós F. El seguimiento farmacoterapéutico como innovación en las farmacias comunitarias de Badajoz (España). Seguimiento Farmacoterapéutico 2004;3(1):10-6.

21. Silva-Castro MM, Bermúdez-Tamayo C, García Gutiérrez JF, Jiménez Pernett J, Tuneu L, Azpilicueta I et al. Recursos Web utilizados por los farmacéuticos para realizar atención farmacéutica. Seguimiento Farmacoterapéutico 2004;2(1):19-23.

22. Andrés Jácome J, Iñesta García A, Huetos Ruiz J, Rodrigo García N. Conocimiento de la técnica de inhalación de medicamentos antiasmáticos por farmacéuticos comunitarios. Pharm Care Esp 2004;6(4):191-4.

23. Rodríguez Chamorro A, Rodríguez Chamorro MA. Conocimiento e implantación del seguimiento farmacoterapéutico por el farmacéutico. Seguimiento Farmacoterapéutico 2005;3(2):98-102.

24. Hidalgo Cabrera J, Cámara Núñez D, Baena MI, Fajardo PC, Martínez-Martínez F. Barreras para la implantación del seguimiento farmacoterapéutico en las farmacias comunitarias de Granada (España). Seguimiento Farmacoterapéutico 2005;3(3):144-9.

25. Durán I, Martínez-Romero F, Faus MJ. ¿A qué población atendemos como farmacéuticos? ¿Cuáles son sus necesidades?. Pharm Care Esp 1999;1(4):258-63.

26. Barris Blundell D, Rodríguez Zarzuelo C, Salinas Muñoz MM, Zarzuelo Pastor C. Demanda de antibióticos orales sin receta médica en una farmacia comunitaria. Pharm Care Esp 2001;3(6):412-20.

27. De Miguel Crisóstomo E, Suárez de Venegas Sanz C. Automedicación en una farmacia comunitaria: solicitud y actuación del farmacéutico. Pharm Care Esp 2001;3(6):433-8.

28. Angulo E, Jiménez Sesma A, del Álamo J, Garmendia C. Experiencia de educación nutricional en la oficina de farmacia. Rev Esp Nutr Comunitaria 2002;8(1-2):42-5.

29. Martí Benavent MA, Estrugo Chuliá F, Martínez Martínez MI. Mujer y climaterio. Una experiencia en el medio rural desde la óptica de la farmacia comunitaria. Pharm Care Esp 2003;5(1):13-21.

30. Fornos Pérez JA, Andrés Rodríguez NF, Guerra García MM. Diseño y validación de un cuestionario de conocimiento sobre diabetes en pacientes de farmacia comunitaria. Pharm Care Esp 2003;5(6):268-74.

31. García-Delgado A, Machuca M, Murillo MD, de la Matta MJ, Martín MJ. Percepción de la labor asistencial del farmacéutico comunitario por los pacientes incluidos en un programa de seguimiento farmacoterapéutico. Seguimiento Farmacoterapéutico 2003;1(2):38-42.

32. Ferrer I, Murillo MD, Machuca M. Determinación del grado de conocimiento y correcta utilización sobre anticonceptivos orales en farmacia comunitaria. Seguimiento Farmacoterapéutico 2003;1(3):136-8.

33. Rodríguez Chamorro MA, Rodríguez Chamorro A, García Jiménez E. Conocimiento y satisfacción por el seguimiento farmacoterapéutico de los pacientes incluidos en el programa Dáder en dos farmacias rurales. Seguimiento Farmacoterapéutico 2004;2(2):286-90.

34. Atozqui J, Díez Noguera A. Determinación del grado de satisfacción en el uso de un sistema personalizado de dosificación. Pharm Care Esp 2004;6(2):91-4.

35. Álvarez de Toledo Saavedra F, Aldasoro Martín MP, Rozas Elizalde E, Fernández Rodríguez S. La toma de tensión arterial en la farmacia comunitaria: un servicio orientado a la Atención Farmacéutica. Pharm Care Esp 2004;6(2):66-70.

36. Amariles $P$, Baena MI, Faus MJ, Machuca M, Tudela J, Barris $D$ et al. Conocimiento y riesgo cardiovascular en pacientes en tratamiento con medicamentos cardiovasculares. Ars Pharmaceutica 2005;46(3):279-300.

37. Andrés Iglesias JC, Andrés Rodríguez NF, Fornos Pérez JA. Validación de un cuestionario de conocimientos sobre hipercolesterolemia en la farmacia comunitaria. Seguimiento Farmacoterapéutico 2005;3(4):189-96.

38. Bertrán Serracanta R, García García I. Grado de conocimiento de las usuarias sobre los anticonceptivos orales en farmacia comunitaria. Pharm Care Esp 2005;7(1):4-6.

39. Climent Catalá MT, Velert Vila J, Velert Vila MM, Salar Ibáñez L, Pastor Bernat Y, Pascual Fos I et al. Papel del farmacéutico en la información al paciente sobre la TSH. Pharm Care Esp 2005;7(1):17-22.

40. Rayón P, Serrano-Castro M, del Barrio H, Álvarez C, Montero D, Madurga M et al. Hypnotic drug use in Spain: a crosssectional study based on a network of community pharmacies. Spanish Group for the Study of Hypnotic Drug Utilization. Ann Pharmacother 1996;30(10):1092-100. 
41. Espejo Guerrero J, Martínez Baca C, Espejo Guerrero A. Análisis de la utilización de antibióticos en una farmacia comunitaria. Farm Clin 1997;14(4):270-4.

42. Espejo Guerrero J, Martínez Baca C. Efectividad de la glimepirida: análisis de una serie de casos. Pharm Care Esp 1999;1(2):123-6.

43. Vázquez Gómez I, Fernández-LLimós F. Aspecto físico de las especialidades farmacéuticas españolas. Pharm Care Esp 1999;1(3):194-7.

44. Modamio P, Sans N, March MA, Mariño EL. Estudios de utilización de medicamentos: antihipertensivos. Pharm Care Esp 1999;1(4):251-7.

45. Del Arco J, García de Vicuña B, Gorostiza I. Análisis del consumo de antibióticos en Deusto (Bizkaia). Pharm Care Esp 1999;1(5):343-53.

46. Machuca González M, Espejo Guerrero J, Gutiérrez Aranda L, Machuca González M, Herrera Carranza J. Análisis de la prescripción antibiótica en una farmacia comunitaria. Pharm Care Esp 2000;2(6):411-9.

47. Machuca González M, Gutiérrez Aranda L, Romero Barba L, Machuca González M. Análisis de la disponibilidad de medicamentos en una farmacia comunitaria. Pharm Care Esp 2001;3(1):22-30.

48. García Caudevilla M, Higueras Aranda MI, Samaniego Silva LR, Cuchí Alfaro T, Bartolomé Rodríguez M. Estudio de utilización de vigabatrina en farmacias comunitarias de Aragón. Pharm Care Esp 2001;3(5):391-392.

49. Gorostiza Hormaetxe I, Jaio Atela N, Armendáriz Cuñado M. Estudio de utilización de antiinflamatorios no esteroideos en farmacia comunitaria. Uso y limitaciones del indicador DCD. Aten Farm 2001;3(6):392-403.

50. Fajardo Paredes P, Baena Parejo MI, Fernández-Llimós F, Faus MJ. Análisis de la información sobre las condiciones de conservación fuera del envase original de los medicamentos más prescritos. Pharm Care Esp 2001;3(6):422-32.

51. Pascual J, Fite B, Lopez-Gil A. Comparison of triptan tablet consumption per attack: a prospective study of migraineurs in Spain. Headache 2002;42(2):93-8.

52. Sánchez Navarro MD, Coloma Milano C, Zarzuelo Castañeda A, Sayarelo Marinero ML, Sánchez Navarro A. Pharmacokinetics of ciprofloxacin as a tool to optimise dosage schedules in community patients. Clin Pharmacokinet 2002;41(14):1213-20.

53. Díaz Paradela M, Díaz Mantis R, Bravo Díaz L, Marhuenda Requena E. Estudio de utilización de medicamentos hipolipemiantes en la provincia de Huelva. Pharm Care Esp 2002;4(1):31-40.

54. Sánchez Navarro MD, Coloma Milano C, Sayalero Marinero ML, Sánchez Navarro A. Atención farmacéutica en antibioterapia: fluoroquinolonas. Pharm Care Esp 2002,4(2):87-99.

55. Gastelurrutia MA, Larrañaga Arregui B, Ortega Arteaga B, Puntonet García L. Evaluación del programa racional de antibióticos en Gipuzkoa. Primera fase: 1999-2000. Pharm Care Esp 2002;4(3);143-57.

56. Barris D, Rodríguez Zarzuelo C, Salinas Muñoz MM, Sabio Sánchez B, Zarzuelo C. Aproximación epidemiológica de la utilización de hipolipemiantes en una farmacia comunitaria. Pharm Care Esp 2002;4(5):358-66.

57. Galán Parra MD, Galán Parra IR, Fal Ordóñez MP, Mulero Flores M, Sánchez Matamoros C. Efectividad de la terapia sustitutiva con nicotina en la deshabituación tabáquica y solución de los problemas relacionados con la medicación. Pharm Care Esp 2002;4(5):367-76.

58. Artetxe Aranzamendi E. Estudio de utilización de antibióticos en una farmacia comunitaria. Pharm Care Esp 2003;5(6):253-60.

59. Diaz Paradela M, Díaz Mantis R, Bravo Díaz L, Marhueda Requena E. Estudio de Utilización de Medicamentos betabloqueantes en la provincia de Huelva. Pharm Care Esp 2003;5(3):120-3.

60. Ezquieta MF, Igoa R. Uso de benzodiazepinas y su adecuación a las últimas instrucciones de la Agencia Española del medicamento. Pharm Care Esp 2003;5(3):116-9.

61. Diaz Paradela M, Díaz Mantis R, Bravo Díaz L, Marhueda Requena E. Estudio de Utilización de Medicamentos del Grupo Terapéutico C02 (Antihipertensivos) en la provincia de Huelva. Pharm Care Esp 2003;5(1):22-8.

62. Rodríguez Martínez MJ, Repilado Grillo F. Seguimiento y control de la pérdida de peso en la oficina de farmacia. Pharm Care Esp 2003;5(2):111

63. Leira R, Dualde E, del Barrio H, Machuca M, López-Gil A; Spanish Group for the Study of Triptan Consumption in Community Pharmacies. Almotriptan versus rizatriptan in patients with migraine in Spain. Headache 2003;43(7):734-41.

64. Huetos Ruiz J. Importancia de la cronoterapia en la hipertensión arterial. Pharm Care Esp 2004;6(3):119-26.

65. Vidal Miquel A, Benet Català A, Ortín Font F, Caelles Franch N. Fármacos de liberación retardada o con cubierta entérica: ¿se utilizan correctamente?. Aten Primaria 2004;34(10):541-7.

66. Barris Blundell D, Rodríguez Zarzuelo C, Sabio Sánchez B, Garrido Jiménez B, Martínez-Rey Jiménez A, Gutiérrez Álvarez JL. ¿Utilizan correctamente los inhaladores los pacientes de una farmacia comunitaria?. Pharm Care Esp 2004;6(1):15-21.

67. Barris D, Rodríguez Zarzuelo C, Sabio B, Garrido B, Gutiérrez Álvarez JL, Martínez-Rey A. Evolución de la demanda de antibióticos orales sin receta en una farmacia comunitaria. Seguimiento Farmacoterapéutico 2005;3(2):84-9.

68. Gorostiza Hormaetxe I, Del Arco Ortiz de Zarate J, Aburto Goiri AM, García Pérez MC, Mateo Domeño JM, Sánchez Ojanguren MJ. Evaluación de una campaña sobre el uso adecuado de laxantes en las farmacias comunitarias. Farm Clin 1995;12(1):18-27.

69. Granados Tejero C, Cobo García M, Martínez López M, Arrazola Saniger M. Reacciones adversas en pacientes monitorizados en una farmacia comunitaria. Farm Clin 1998;15(6):359-67.

70. Gastelurrutia MA, Larrañaga B, Ortega B, Garai A. Educación sanitaria y detección de hipertensos ocultos en las Oficinas de Farmacia de Gipuzkoa. Pharm Care Esp 1999;1(4):244-50.

71. De Diego Berlinches A, Alvarellos Bermejo ML, Del Barrio Sánchez H. Análisis de la compleción de la base de datos del Consejo General de Colegios Oficiales de Farmacéuticos sobre interacciones entre medicamentos. Pharm Care Esp 1999;1(3):184-93. 
72. Galán Parra MD, Galán Parra IR, López Delgado C, González Villa L, Sánchez López MC, Bermúdez Loizaga AI. Efectividad de la solución tópica de minoxidil en fórmula magistral y resolución de los Problemas Relacionados con el Medicamento. Pharm Care Esp 1999;1(6):403-11.

73. Fernandez-Llimós F, Loza MI. Product monographs supplied by drug manufacturers to community pharmacists in Spain. Ann Pharmacother 2000;34(3):407.

74. Prado MC, Porres I, Feo M, Funoll M, Pérez M, Valladares MC et al. Análisis de la información sobre el contenido en gluten de las especialidades farmacéuticas. Pharm Care Esp 2001;3(2):122-30.

75. Jodral AM, Parras M, Morcillo F, López Cobelo J, Fernández F. Análisis de la compleción de la base de datos de medicamentos den Consejo General de Colegios Farmacéuticos: Las Contraindicaciones. Pharm Care Esp 2002;4(5):351-7.

76. García Soláns JR. Programa de Farmacovigilancia con inhibidores de la bomba de protones en farmacias de Zaragoza. Pharm Care Esp 2002;4(3);168-74.

77. Junquera E, Gurrea A, Crespo E, Vázquez Gómez I. Evaluación de los boletines de análisis de las materias primas para formulación magistral. Pharm Care Esp 2002;4(4);222-30.

78. Barris Blundell D. Sospechas de reacciones adversas a medicamentos notificadas en una farmacia comunitaria. Pharm Care Esp 2002;4(4):250-1.

79. De Miguel E, Suárez De Venegas C. Implantación de un programa de seguimiento de personas con sobrepeso y obesidad como paso previo al seguimiento farmacoterapéutico. Pharm Care Esp 2002;4(5):264-74.

80. Guerra García MM, Fornos Pérez JA, Andrés Rodríguez NF. Detección de diabéticos no diagnosticados en las farmacias comunitarias de la provincia de Pontevedra. Pharm Care Esp 2003;5(4):166-169.

81. Salgueiro Vázquez ME, Bermúdez Del Sol A, Llavota Hevia A, Monteserín Fernández MS, Sánchez Álvarez L, Revuelta Bayod $\mathrm{P}$ et al. La notificación espontánea de reacciones adversas desde una oficina de farmacia. Pharm Care Esp 2003;5(5):226-31.

82. Aguilar A, Cansino J, Giné N, Matas MD, Miras M, Valdayo L. Información sobre la seguridad en asma, diabetes e hipertensión de las especialidades farmacéuticas sin receta, según distintas fuentes terciarias. Seguimiento Farmacoterapéutico 2003;1(3):115-9.

83. Navarro Pemán MC, García Caudevilla M, Higueras Aranda MI, Cuchí Alfaro T, Bartolomé Rodríguez M. Programa de Farmacovigilancia en Oficinas de Farmacia: Estudio de utilización de moxifloxacino. Pharm Care Esp 2004;6(1):22-7.

84. Hernández EB, Llamas JM, Orenes M, Salmerón J, Tomás E. Educación sanitaria: el botiquín casero. Seguimiento Farmacoterapéutico 2004;2(1):46-9.

85. Vázquez Gómez I, Fernández-Llimós F, Gastelurrutia MA. Respuesta de la industria farmacéutica ante una consulta específica. Aten Primaria 2005;35(4):219-20.

86. Bernárdez M, Puche E, Martínez B, García Morillas M, Luna JD. Estudio farmacoepidemiológico a largo plazo sobre dispensación de fármacos por la oficina de farmacia en AP rural. Influencia de edad y sexo. Aten Primaria 1997;19(1):7-11.

87. Barbero González JA, De Diego Berrinches A, Del Barrio Sánchez H, Pastor-Sánchez R. Sustituciones de medicamentos en oficinas de farmacia de la Comunidad de Madrid. Aten Primaria 1999;23(9):526-32.

88. Barbero González JA, Alfonso Galán T. Detección y resolución de problemas relacionados con los medicamentos en la farmacia comunitaria: una aproximación. Pharm Care Esp 1999;1(2):113-22.

89. Ibáñez Fernández J, Caelles Franch N, Rodríguez Galindo L, Fernández Cabré E, García Manzanares M, Tuneu Valls L. Análisis de la cumplimentación de las recetas en algunas farmacias comunitarias. Pharm Care Esp 1999;1(3):198201.

90. Gutiérrez Rodríguez S, Alvarellos Bermejo ML, Del Barrio Sánchez H. Dispensación de medicamentos antirretrovirales en la oficina de farmacia. Pharm Care Esp 2001;3(3):188-94.

91. Moreno Izquierdo F. Implantación de dispositivos de ayuda al cumplimiento en una Farmacia Comunitaria. Análisis de costes. Pharm Care Esp 2001;3(5):337-44.

92. Fernández Román M. Índice de errores de dispensación en una farmacia. Pharm Care Esp 2002;4(1);66-7.

93. Berguillos Moretón L, López González I, Zardain Tamargo E, Comas Vega R. Factibilidad de implantación de un modelo de dispensación activa de medicamentos con receta en oficinas de farmacia asturianas. Estudio piloto. Pharm Care Esp 2003;5(6):247-52.

94. Barris Blundell D, Rodríguez Zarzuelo C, Sabio Sánchez B, Garrido Jiménez B. Interacciones farmacológicas detectadas en una farmacia comunitaria. Pharm Care Esp 2003;5(6):261-7.

95. Lozano Sauquillo C, Blasco Segura P, Hernández Marrero MR, Vallcanera Calatayud JL, López Vercer MJ, Just Martínez MJ et al. Estudio de errores de dispensación en Oficinas de Farmacia de Valencia. Pharm Care Esp 2004;6(2):53-8.

96. Acosta Gómez J, Alzaga Lizarralde A, Álvarez Mozos L, Gudiel Urbano M, Fernández-Llimós F. Análisis del proceso de dispensación y detección de interacción potencial en farmacias de Alcorcón (Madrid) y Bilbao. Seguimiento Farmacoterapéutico 2004;2(1):32-6.

97. Rodríguez MJ, Pérez-Accino C, Allúe V, Domingo T, Fernández-Montes T, Gamarra C et al. Registro de las intervenciones del farmacéutico en la dispensación activa: resultados. Seguimiento Farmacoterapéutico 2004;2(1):2931.

98. Vargas R, March MA, Duarte ME, Puig J, Rueda M, Vilar P et al. Hipolipemiantes: estudio de dispensación activa en oficinas de farmacia de la región sanitaria "Costa de Ponent". Pharm Care Esp 2005;7(3):102-5.

99. Gil De San Vicente O, Erauncetamurgil O, De Escalza P, Odriozola, I, Gastelurrutia MA. Evaluación del número de recetas mal cumplimentadas en una farmacia comunitaria. Seguimiento Farmacoterapéutico 2005;3(3):125-9. 
100. Sánchez Torres AM, Creis Márquez J, Arreaza Prado M. Análisis de las consultas al farmacéutico de los usuarios de las farmacias de Ciudad Real. Pharm Care Esp 2001;3(2):106-21.

101. Barbero A, Alfonso Galán T. Consulta de indicación farmacéutica en una Farmacia comunitaria. Pharm Care Esp 2002;4(2):106-17.

102. Machuca M, Oñate B, Machuca MP, Gastelurrutia P, Gutiérrez-Aranda L, López-Fernández E et al. La indicación farmacéutica disminuye las visitas al médico y resuelve las demandas de los pacientes. Seguimiento Farmacoterapéutico 2003;1(3):110-14.

103. Baixauli Fernández VJ, Salar lbáñez L, Barbero González A. Demanda de información en la Farmacia Comunitaria. Pharm Care Esp 2004;6(3):136-44.

104. Baixauli Fernández VJ, Barbero González A, Salar Ibáñez L. Las consultas de indicación farmacéutica en la farmacia comunitaria. Pharm Care Esp 2005;7(2):54-61.

105. Velert Vila MM, Velert Vila J, García Callejo FJ, Salar Ibáñez L. Seguimiento del paciente en indicación farmacéutica. Pharm Care Esp 2005;7(2):62-68.

106. Duran I, Martínez Romero F, Faus MJ. Problemas relacionados con medicamentos resueltos en una farmacia comunitaria. Pharm Care Esp 1999;1(1):11-19.

107. Dualde Viñeta E. Control y seguimiento de medicación en pacientes hipertensos. Pharm Care Esp 1999;1(1):28-34.

108. Martínez-Romero F, Fernández-Llimós F, Gastelurrutia MA, Parras M, Faus MJ. Programa Dáder de Seguimiento del Tratamiento Farmacológico. Resultados de la fase piloto. Ars Pharm 2001;42(1):53-65.

109. Cardo Prats E, Corella Piquer MD, García Cebrián F, Mañes Vinuesa J. Atención Farmacéutica en pacientes hiperlipémicos. Pharm Care Esp 2001;3(2):95-104

110. Barbero González JA. Detección de PRM en la farmacia comunitaria: usuarios registrados versus usuarios no registrados. Pharm Care Esp 2001;3(3):204-15.

111. Cardo Prats E, García Cebrián F. Test de Hamilton ¿Instrumento utilizable por el farmacéutico en el SFT de los pacientes con depresión?. Pharm Care Esp 2002;4(1);41-51.

112. García Caudevilla M, García Jiménez E, Tena M, Urbon A. Seguimiento farmacoterapéutico en las farmacias, por los Colegios Oficiales de Farmacéuticos de Aragón (I): Implantación de la metodología Dáder (Seguimiento Farmacoterapéutico). Pharm Care Esp 2002;4(4):231-41.

113. Salar L, Climent MT, Pascual I, Velert J, Aznar S. Repercusión de PRM en el paciente: Estudio piloto. Pharm Care Esp 2003;5(2):82-87.

114. Barris D, Faus MJ. Iniciación a la metodología Dáder de seguimiento farmacoterapéutico en una farmacia comunitaria. Ars Pharmaceutica 2003;44(3):225-37.

115. Barris Blundell D, Rodríguez Zarzuelo C, Martínez-Rey Jiménez A, Sabio Sánchez B, Gutiérrez Álvarez JL, Garrido Jiménez B. Problemas relacionados con los medicamentos detectados en pacientes que utilizan medicación antiasmática en una farmacia comunitaria. Pharm Care Esp 2004;6(4):202-209.

116. Andrés Jácome J, Iñesta García A. PRM identificados en pacientes asmáticos. Pharm Care Esp 2004;6(4):210-17.

117. Salar Ibáñez L, Climent Catalá MT, Colmenero Navarro LL, García Cebrián F, Pascual Fos I, Velert Vila J. Propuesta de clasificación de PRM según sus causas. Pharm Care Esp 2004;6(3):110-6.

118. Vázquez V, Chacón J, Espejo J, Faus MJ. Resultados del seguimiento farmacoterapéutico en una farmacia comunitaria. Seguimiento Farmacoterapéutico 2004;2(3):189-194.

119. Pérez Ballester T, González Pérez R, Rius Chaves C, Martín Calero MJ. Incidencia del seguimiento farmacoterapéutico en pacientes diabéticos. Seguimiento Farmacoterapéutico 2004;2(4):228-34

120. Paulino El, Bouvy ML, Gastelurrutia MA, Guerreiro M, Buurma H; ESCP-SIR Rejkjavik Community Pharmacy Research Group. Drug related problems identified by European community pharmacists in patients discharged from hospital. Pharm World Sci 2004;26(6):353-60.

121. La Casa García C, Martín Calero MJ, Domínguez Camacho JC, Machuca González M, García-Delgado Morente A, Juárez Manzano J. Eficacia de la intervención farmacéutica en pacientes polimedicados. Pharm Care Esp 2005;7(1):25-31.

122.Sabater D, Fernandez-Llimos F, Parras M, Faus MJ. Tipos de intervenciones farmacéuticas en seguimiento farmacoterapéutico. Seguimiento Farmacoterapéutico 2005;3(2):90-97.

123. Ciller Cortés JA, Acosta Gómez J, Azpeitia González B, Diez Arranz R, Gudiel Urbano M, Gutiérrez Rios $P$ et al. Seguimiento de la salud y de la alimentación del niño en sus 2 primeros años de vida. Seguimiento Farmacoterapéutico 2005;3(1):57-61.

124. Barbero González JA, Quintas Rodríguez AM, Camacho JE. Deshabituación tabáquica desde las farmacias. Aten Primaria 2000;26(10):693-6.

125. Salar Ibáñez L, Dualde Viñeta E, Bernardeu Maestro E, García Cebrián F. Programa TOD (Tratamiento de Observación Directa) de Valencia. Implantación y experiencia iniciales. Pharm Care Esp 2000;2(1):28-41.

126. Álvarez de Toledo F, Arcos González P, Eyaralar Riera T, Abal Ferrer FF, Dago Martínez A, Cabiedes Miragaya L et al. Atención farmacéutica en personas que han sufrido episodios coronarios agudos (estudio TOMCOR). Rev Esp Salud Pública. 2001;75(4):375-87.

127. Martí Font R Vía Sosa MA, Valero Barlabé J, Fernández Martínez MP. Colaboración entre la farmacia hospitalaria y comunitaria en la valoración y mejora del cumplimiento farmacológico de pacientes con patologías crónicas respiratorias. Aten Farm 2001;3(5):337-43.

128. Andrés Jacome J, Iñesta García A. Estudio prospectivo sobre el impacto de un servicio de atención farmacéutica comunitaria en personas asmáticas. Rev Esp Salud Pública 2003;77(3):393-403. 
129. Barbero González A, Álvarez de Toledo Saavedra F, Esteban Fernández J, Pastor-Sánchez R, Gil de Miguel A, Rodríguez Barrios $\mathrm{JM}$ et al. Seguimiento desde la farmacia comunitaria de la vacunación y quimioprofilaxis de los viajeros internacionales. Estudio VINTAF. Aten Primaria 2003;32(5):276-81.

130. Machuca M, Espejo J, Gutiérrez L, Machuca MP, Herrera J. La información escrita del farmacéutico mejora el cumplimiento de la antibioterapia. Ars Pharmaceutica 2003;44(2):141-57.

131. Cociña Abella C, Aranda Gallardo D, Magro Horcajada C. Atención farmacéutica en pacientes con Síndrome de Inmunodeficiencia Adquirida. Pharm Care Esp 2003;5(3):146-150.

132. Andrés JC, Andrés NF, Fornos JA. Evaluación de la intervención farmacéutica sobre cumplimiento en terapia antibiótica. Seguimiento Farmacoterapéutico 2004;2(2):97-102.

133. Martínez Pérez SR, Sánchez Alonso FJ, Baena MI. Efectos de la intervención farmacéutica en pacientes con presión arterial elevada sin tratamiento farmacológico. Seguimiento Farmacoterapéutico 2004;2(3):181-188.

134. Pla Cama L, Faixedas Brunsoms MT, Cabarrocas Durán S, Roig AM. Proyecto coordinado para el manejo de la HTA en la comunidad. Pharm Care Esp 2004;6(1):2-8.

135. Bordons M, Zulueta MA. Evaluación de la actividad científica a través de indicadores bibliométricos. Rev Esp Cardiol 1999;52:790-800.

136. Sociedad Española de Farmacia Hospitalaria [Sede Web]. Revista Farmacia Hospitalaria. Available at: http://www.sefh.es/01revista_farmacia_hospitalaria.php. [Accessed 21-07-2006].

137. Ferriols Lisart R, Montañés Pauls B, Moreno Miralles A, Ventura Cerdá JM. Artículos originales publicados en Farmacia Hospitalaria (1994-1999). Análisis del consumo de información. Farm Hosp 2001;25 (1):38-43.

138. Sáez Gómez JM, Gómez Terradillos D, Ramírez Romero P, Valera Candel M, Aguinaga Ontoso E, Pardo García JL et al. Las revistas nacionales y extranjeras como fuente de información científica de los cirujanos españoles. Cir Esp 2000;68:144-149.

139. Aleixandre R, Giménez Sánchez JV, Terrada ML, López Piñero JM. Análisis del consumo de información en la revista Medicina Clínica. Med Clin (Barc) 1994;103(7):246-51.

140. Argimon Pallás JM, Jiménez Villa J. Métodos de investigación clínica y epidemiológica. $2^{\mathrm{a}}$ ed. Madrid: Harcourt; 2000.

141. ISI Web of Knowledge [Base de datos en Internet]. Journal Citation Reports. Available at: http://www.bugalicia.org/interface. asp?idRecurso=52. (accessed 14-07-2006].

142. Aleixandre Benavent R, Valderrama Zurián JC, Castellano Gómez M, Miguel-Dasit A, Simo Meléndez, Navarro Molina C. Factor de impacto nacional e internacional de Revista Española de Cardiología. Rev Esp Cardiol 2004;57(12):12414.

143. Factor de Impacto Potencial de las Revistas Médicas Españolas. Disponible en: http://147.156.181.37/imecitas/impacto_ime.asp. (accessed 23-05-2006].

144. Fernández-Llimós F. Análisis de la cobertura del concepto de Pharmaceutical Care en fuentes primarias y secundarias de información [Tesis Doctoral]. Granada: Universidad de Granada; 2003.

145. Kennie NR, Schuster BG, Einarson TR. Critical analysis of the pharmaceutical care research literature. Ann Pharmacother 1998;32(1):17-26.

146. Canadian Task Force on Preventive Health Care [Sede Web]. History and methods: Levels of Evidence - Research Design Rating. Available at: http://www.ctfphc.org. (accessed 15-06-2006)

147. Moher D, Schulz KF, Altman DG. La declaración CONSORT: Recomendaciones revisadas para mejorar la calidad de los informes de ensayos aleatorizados de grupos paralelos. Rev Sanid Milit Mex 2002;56:23-8. 